\title{
DISKURSUS SOSIOLOGI PUTUSAN MAHKAMAH KONSTITUSI NOMOR 46/PUU-VIII/2010
}

\author{
Dwi Sakti Muhamad Huda ${ }^{1 *}$, Dodi Alaska Ahmad Syaiful ${ }^{2}$, Desi Wahyuni ${ }^{3}$ \\ ${ }^{1}$ Pengadilan Agama Kota Manna, INDONESIA \\ ${ }^{2}$ Universtias Islam Negeri Lampung, INDONESIA \\ ${ }^{3}$ Universtias Islam Negeri Yogyakarta, INDONESIA \\ *Correspondence: $\square$ hudadsmh@gmail.com
}

\begin{abstract}
The Constitutional Court Decision Number 46 / PUU-VIII / 2010 annulled the provisions of Article 43 paragraph (1) of the Marriage Law because it contradicts the 1945 Constitution of the Republic of Indonesia and does not have binding legal force. The legal reason behind the recht finding is to emphasize that children born outside of marriage have the right to legal protection. This research was conducted with the aim of knowing the impact of the Constitutional Court Decision Number 46 / PUU-VIII / 2010 on one of the judges' judicial duties. This study uses a socio-legal approach with data collection techniques for study documents of literature materials. Based on the results of the analysis of the Constitutional Court Decision Number 46 / PUU-VIII / 2010, it does not contradict and intersect with sociological discourse in accordance with the argumentum a contrario method. Then have coherence between the parental or bilateral kinship system with the Constitutional Court Decision No. 46 / PUU-VIII / 2010 in its application in Indonesia. This condition demands the intellectuality of Judges who are required to think on a broad scale and consider other disciplines in their legal findings.
\end{abstract}

\begin{abstract}
Abstrak
Putusan Mahkamah Konstitusi Nomor 46 / PUU-VIII / 2010 membatalkan ketentuan Pasal 43 ayat (1) UU Perkawinan karena bertentangan dengan Undang-Undang Dasar Negara Republik Indonesia Tahun 1945 dan tidak memiliki kekuatan hukum mengikat. Alasan hukum di balik recht finding adalah untuk menegaskan bahwa anak yang lahir di luar nikah berhak atas perlindungan hukum. Penelitian ini dilakukan dengan tujuan untuk mengetahui dampak Putusan Mahkamah Konstitusi Nomor 46 / PUU-VIII / 2010 terhadap salah satu tugas peradilan hakim. Penelitian ini menggunakan pendekatan sosio-legal dengan teknik pengumpulan data studi dokumen bahan pustaka. Berdasarkan hasil analisis Putusan Mahkamah Konstitusi Nomor 46 / PUU-VIII / 2010 tidak bertentangan dan bersinggungan dengan wacana sosiologis yang sesuai dengan metode argumentum a contrario. Kemudian memiliki keterpaduan antara sistem kekerabatan orang tua atau bilateral dengan Putusan Mahkamah Konstitusi Nomor 46 / PUU-VIII / 2010 dalam penerapannya di Indonesia. Kondisi ini menuntut intelektualitas hakim yang dituntut untuk berpikir secara luas dan mempertimbangkan disiplin ilmu lain dalam temuan hukumnya.
\end{abstract}

(C) 2020 Dwi Sakti Muhamad Huda, Dodi Alaska Ahmad Syaiful, Desi Wahyuni

This work is licensed under a Creative Commons Attribution-ShareAlike 4.0 International License.

\section{A. Pendahuluan}

Manusia adalah zoon politicon dan melalui adanya interaksi antar sesama, maka secara alamiah manusia memiliki dorongan untuk mempertahankan keadaannya dalam masyarakat. 


\section{DISKURSUS SOSIOLOGI PUTUSAN...}

Penting bagi manusia untuk mempertahankan garis keturunan dalam masyarakat. ${ }^{1}$ Sehingga dengan adanya keturunan atau penerus keluarga, status atau kedudukan yang melekat dalam diri manusia di masyarakat dapat diteruskan dan bertahan.

Beberapa tahun lalu masyarakat di Indonesia di kejutkan oleh Putusan Mahkamah Konstitusi Nomor 46/PUU-VIII/2010 yang menganulir ketentuan Pasal 43 ayat (1) Undang-Undang Perkawinan karena bertentangan dengan Undang-Undang Dasar Negara Republik Indonesia Tahun 1945 dan tidak memiliki kekuatan hukum mengikat sepanjang dimaknai menghilangkan hubungan perdata dengan laki-laki yang dapat dibuktikan berdasarkan ilmu pengetahuan dan teknologi dan/atau hubungan darah sebagai ayah. Alasan hukum yang melatarbelakangi adanya rechtfinding tersebut adalah untuk menegaskan bahwa anak yang lahir diluar pernikahan berhak mendapat perlindungan hukum. ${ }^{2}$ Hal tersebut membuka titik terang dengan adanya keharusan memberi perlindungan dan kepastian hukum yang adil terhadap status seorang anak beserta hak- haknya mesikpun keabsahan perkawinannya masih disengketakan. Sehingga, hubungan antara ayah dan anak dapat dikukuhkan berdasarkan proses hukum.

Begitu banyak kontroversi yang terjadi setelah problematika tersebut diketuk palu oleh Mahkamah Konstitusi pada tahun 2012. Kemudian menjadi lebih ramai pada saat Menteri Agama Suryadharma Ali memberikan statementnya perihal hal tersebut. Dikatakannya " $M K$ mengabulkan lebih besar dari yang dimohonkan atau diminta. Namun dengan keputusan MK tersebut, dampaknya menjadi luas. Kemudian dengan keputusan MK tersebut, terkesan melegalkan anak hasil pelacuran, pemerkosaan, kumpul kebo. Melihat dari sisi tersebut di mana letak hukum Islamnya. Sementara UU Perkawinan berdasarkan Islam, apakah kemudian hal-hal tersebut akan terus dibiarkan dan merajalela". ${ }^{3}$ Hal tersebut diperkuat dengan adanya putusan dari Majelis Ulama Indonesia yang menentang putusan Mahkamah Konstitusi. Pada prinsipnya MUI menentang penashaban anak yang lahir diluar pernikahan terhadap ayah biologisnya yang berlandaskan pada Qur'an, hadits, dan pendapat ulama klasik. ${ }^{4}$

Putusan Mahkamah Konstitusi sebagaimana telah diuraikan di atas tidak mengubah status anak luar kawin menjadi anak sah atau sama kedudukannya dengan status anak yang dilahirkan dari perkawinan di bawah tangan sekalipun atau sebaliknya status anak yang lahir dari perkawinan di bawah tangan sama kedudukannya dengan anak luar nikah. Akan tetapi putusan tersebut memperluas hubungan keperdataan yang tidak hanya terbatas pada hubungan keperdataan antara anak luar kawin dengan ibunya dan keluarga ibunya saja melainkan juga mempunyai hubungan keperdataan dengan bapaknya yang mengakibatkan kelahirannya dan hubungan keperdataan dengan keluarga bapaknya apabila hal itu dapat dibuktikan berdasarkan ilmu pengetahuan dan teknologi dan/atau alat bukti lain menurut hukum mempunyai hubungan darah. ${ }^{5}$

Penelitian mengenai Putusan Mahkamah Konstitusi Nomor 46/PUU-VIII/2010 sudah banyak dilakukan. Pada tahun 2015 Moch Fahruz Rizqy melakukan penelitian mengenai Implikasi Yuridis

\footnotetext{
${ }^{1}$ Fikri Hakim, Nani Darmayanti, and Ani Rachmat, "Pemberitaan Konflik Antara Viking Dan Jakmania Dalam Viva.Co.Id: Suatu Kajian Wacana Kritis,” Jurnal Linguistik Terapan 8, no. 1 (May 31, 2018): 33-41.

${ }^{2}$ Gratia Nathania Tanuraharja, "Implikasi Putusan Mahkamah Konstitusi Nomor 46/PUU-VIII/2010 Terhadap Bagian Waris Anak Luar Kawin,” E-Journal Universitas Atma Jaya Yogyakarta, December 13, 2015, 1-11.

3 Taufik Rachman, “Menag: Putusan MK Melebihi Permohonan Machica Mochtar,” Republika Online, April 10, 2012, https://republika.co.id/berita/nasional/hukum/12/04/10/m29gey-menag-putusan-mk-melebihi-permohonanmachica-mochtar.

${ }^{4}$ Amran Suadi and Mardi Candra, Politik Hukum: perspektif hukum perdata dan pidana Islam serta ekonomi syariah (Jakarta: Prenada Media, 2016), h: 54.

${ }^{5}$ Dadang Iskandar, "Politik Hukum Mahkamah Konstitusi Tentang Status Anak Luar Kawin Dalam Putusannya Nomor 46/PUU-VIII/2010,” YUSTISI 2, no. 1 (April 5, 2016): 27, https://doi.org/10.32832/yustisi.v2i1.197.
} 
DISKURSUS SOSIOLOGI PUTUSAN...

Putusan Mk Nomor 46/PUUVIII/2010 Terkait Perlindungan Hak Anak. Hasil dari penelitiannya menegaskan bahwa ayah biologis atau kandung merupakan pihak yang bertanggung jawab terhadap perlindungan anak sebagaimana terdapat dalam ketentuan UU Perlindungan Anak. ${ }^{6}$

Kemudian penelitian yang dilakukan oleh Hardian Mukti Adi mengenai Pengaruh Putusan Mahkamah Konstitusi Nomor 46/PUU-VII 2010 Terhadap Hak Waris Anak Yang Lahir Di Luar Kawin Menurut Kitab Undang-Undang Hukum Perdata. Faktanya masih banyak hak-hak anak yang belum terlindungi secara sempurna. Seorang anak berhak mendapatkan perlindungan dan kepoastian hukum yang adil, karena pada dasarnya hukum tidak pernah mengenal istilah dosa turunan. Anak yang lahir diluar pernikahan dapat menjadi ahli waris dengan kriteria bahwa ahli waris golongan I, bagiannya: 1/3 dari bagiannya seandainya ia anak sah, anak lahir diluar pernikahan menjadi ahli waris golongan II dan III, bagiannya: 1/2 dari seluruh warisan dan Anak lahir diluar pernikahan menjadi ahli waris golongan IV, bagiannya: $3 / 4$ dari seluruh warisan serta hak waris bagi anak lahir diluar pernikahan sesuai dengan Putusan Mahkamah Konstitusi No.46/PUU$\mathrm{VIII} / 2010 .^{7}$

Penelitian yang dilakukan oleh Nurhadi Mahkamah Syaríyah Sabang mengenai Implementasi Putusan Mahkamah Konstitusi Nomor 46/PUU-VIII/2010 Tentang Anak Di Luar Kawin: Kajian Putusan Nomor 329 K/AG/2014 menegaskan bahwa dalam putusan tersebut lebih mengutamakan aspek yuridis, sedangkan aspek sosiologis dan filosofis cenderung diabaikan. Putusan Nomor 329 K/AG/2014 tersebut tidak mengimplementasikan Putusan Mahkamah Konstitusi Nomor 46/PUUVIII/2010. Berdasarkan teori keadilan, teori perlindungan hukum, teori kewenangan, teori hukum progresif, dan teori mashlahah, petitum tentang anak di luar kawin dapat dikabulkan. ${ }^{8}$

Terlepas dari segala kontroversi tersebut, bahkan sampai sekarang masih sering menjadi bahan diskusi dikalangan akademis maupun praktisi, mulai dari obrolan warung kopi sampai forum litigasi. Penulis cenderung tertarik mengkajinya secara sosiologis, yaitu apakah Putusan Mahkamah Konstitusi Nomor 46/PUU-VIII/2010 dalam proses dan pasca dikabulkannya bersinggungan dengan diskursus sosiologis, dan apakah dalam proses dan pasca dikabulkannya bersinggungan dengan diskursus sosiologis

Penyusunan artikel ini bertujuan untuk menambah khazanah ilmu pengetahuan sekaligus mengetahui sejauh mana impact Putusan Mahkamah Konstitusi Nomor 46/PUU-VIII/2010 terhadap salah satu tugas yustisial hakim. Hakim dalam menyelesaikan perkara-perkara yang diajukan kepadanya, wajib memperhatikan dengan sungguh-sungguh nilai-nilai hukum yang hidup dalam masyarakat, sehingga putusannya sesuai dengan rasa keadilan.

\section{B. Metode Penelitian}

Penelitian ini bersifat deskriptif analitis dengan menggunakan pendekatan sosio legal yakni pendekatan yang melihat hukum melalui penggabungan antara analisa normatif (norma-norma hukum dan yuridis). Teknik pengumpulan data dalam penelitian ini melalui studi dokumen bahan kepustakaan meliputi putusan pengadilan, beberapa literatur review penelitian terdahulu, buku-buku literatur, kamus hukum, ensiklopedia, majalah, surat kabar, internet, dan jurnal-jurnal yang

\footnotetext{
${ }^{6}$ Mochammad Fahruz Rizqy, "Implikasi Yuridis Putusan Mk Nomor 46/Puu-Viii/2010 Terkait Perlindungan Hak Anak," Yuridika 30, no. 2 (May 9, 2015): 278-306, https://doi.org/10.20473/ydk.v30i2.4652.

${ }^{7}$ Hardian Mukti Adi, "Pengaruh Putusan Mahkamah Konstitusi Nomor 46/Puu-Viii 2010 Terhadap Hak Waris Anak Yang Lahir Di Luar Kawin Menurut Kitab Undang-Undang Hukum Perdata,” Jurnal Hukum Prodi Ilmu Hukum Fakultas Hukum Untan (Jurnal Mahasiswa S1 Fakultas Hukum) Universitas Tanjungpura 4, no. 1 (December 16, 2015), https://jurnal.untan.ac.id/index.php/jmfh/article/view/12842.

${ }^{8}$ Nurhadi Nurhadi, "Implementasi Putusan Mahkamah Konstitusi Nomor 46/Puu-Viii/2010 Tentang Anak Di Luar Kawin,” Jurnal Yudisial 11, no. 2 (August 30, 2018): 243-65, https://doi.org/10.29123/jy.v11i2.66.
} 


\section{DISKURSUS SOSIOLOGI PUTUSAN..}

berkaitan dengan fokus penelitian ini.

\section{Pembahasan atau Analisis}

\section{Putusan Hakim}

Hakim selalu dihadapkan pada peristiwa konkrit dimana hakim harus memberikan jalan keluar atau memberikan suatu pertimbangan yang dapat diterima secara nalar dalam suatu putusannya yang mempunyai kekuatan mengikat sebagai hukum dan menjadi suatu sumber hukum (yurisprudensi). Hakim tidak boleh menolak untuk memeriksa, mengadili dan memutuskan suatu perkara yang diajukan kepadanya dengan dalih bahwa hukumnya tidak ada atau kurang jelas. ${ }^{9}$

Undang-undang mengenai kekuasaan kehakiman menyatakan bahwa hakim wajib menggali, mengikuti, dan memahami nilai-nilai hukum dan rasa keadilan yang hidup dalam masyarakat. ${ }^{10}$ Hal tersebut mengandung arti bahwa hakim dalam menjalankan tugas dan wewenangnya bebas dari intervesi siapapun, dan tidak indepenen dalam menjatukan putusan. Seorang Hakim harus memiliki kemampuan dan keaktifan untuk menemukan hukum (Rechtfinding).

Setiap putusan hakim seyogyanya merefleksikan pertimbangan moral. Moral merupakan nilai keabsolutan dalam kehidupan bermasyarakat secara utuh. Moralitas suatu perbuatan menyatakan bahwa perbuatan itu sesuai dengan kaidah moral (morele wetten). Sedang legalitas suatu perbuatan menyatakan bahwa perbuatan itu sesuai dengan kaidah hukum (juridische wetten). Dalam konteks putusan hakim, maka kedudukan moral memegang peranan sebagai pengendali (sturende)dan refleksi motivasi diri seorang hakim dalam proses pengambilan putusan. Putusan hakim yang lahir dari proses kontemplasi moral baik dari segi lahiriah maupun batiniah akan menghasilkan putusan hakim yang adil, karena putusan hakim yang berbasis moral tentu saja telah koheren dengan pertimbangan fakta, norma, doktrin baik dari segi lahiriah maupun batiniah serta lebih komprehensif dan utuh. ${ }^{11}$

Tujuan diadakannya suatu proses di muka peradilan adalah untuk memperoleh putusan hakim. ${ }^{12}$ Semua putusan pengadilan harus memuat alasan-alasan putusan yang dijadikan dasar untuk mengadili (Pasal 23 UU No. 14/1970; Pasal 184 ayat 1 dan Pasal 319 HIR; Pasal 195 dan 618 $\mathrm{RBg}$ ). Alasan-alasan atau argumentasi itu dimaksudkan sebagai pertanggungjawaban hakim dari pada putusannya terhadap masyarakat, para pihak, pengadilan yang lebih tinggi dan ilmu hukum, sehingga oleh karenanya mempunyai nilai obyektif. Karena adanya alasan-alasan itulah maka putusan mempunyai wibawa dan bukan karena hakim tertentu yang menjatuhkannya. ${ }^{13}$

Jenis putusan dilihat dari amarnya dapat dibedakan antara putusan yang bersifat declaratoir, constitutief dan condemnatoir. Putusan declaratoir adalah putusan di mana hakim menyatakan apa yang menjadi hukum. Putusan constitutief adalah putusan yang meniadakan satu keadaan hukum atau menciptakan satu keadaan hukum yang baru. Sedangkan putusan condemnatoir adalah putusan

${ }^{9}$ Edi Rosadi, "Putusan Hakim Yang Berkeadilan,” Badamai Law Journal 1, no. 2 (September 27, 2016): h: 383, https://doi.org/10.32801/damai.v1i2.1850.

10 Benny K. Harman, Mempertimbangkan Mahkamah Konstitusi (Jakarta: Kepustakaan Populer Gramedia, 2013), h: 245.

${ }^{11}$ HM Soerya Respationo and M. Guntur Hamzah, "Putusan Hakim: Menuju Rasionalitas Hukum Refleksif Dalam Penegakan Hukum," Yustisia Jurnal Hukum 2, no. 2 (May 1, 2013): h: 104, https://doi.org/10.20961/yustisia.v2i2.10194.

${ }^{12}$ Amran Suadi, Penyelesaian Sengketa Ekonomi Syariah Teori dan Praktik Ed Revisi (Jakarta: Kencana, 2017), h: 181.

13 Dian Latifiani, "Permasalahan Pelaksanaan Putusan Hakim,” ADHAPER: Jurnal Hukum Acara Perdata 1, no. 1 (2015): 15-29-29. 


\section{DISKURSUS SOSIOLOGI PUTUSAN...}

yang berisi penghukuman terhadap tergugat atau termohon untuk melakukan satu prestasi. ${ }^{14}$

Amar putusan dalam putusan Mahkamah Konstitusi No. 46/PUU-VIII/2010 menerangkan apa yang menjadi hukum (declaratoir) Pasal 43 ayat (1) UU No. 1/1974 yang berbunyi, "anak yang dilahirkan di luar perkawinan hanya mempunyai hubungan perdata dengan ibunya dan keluarga ibunya”, bertentangan dengan Undang-Undang Dasar 1945 sepanjang dimaknai menghilangkan hubungan perdata laki-laki yang dapat dibuktikan berdasarkan ilmu pengetahuan dan teknologi dan/atau alat bukti lain menurut hukum mempunyai hubungan darah sebagai bapaknya.

Setiap anak mempunyai harkat dan martabat yang patut dijunjung tinggi dan setiap anak yang terlahir harus mendapat hak-haknya tanpa anak tersebut meminta. Hak tersebut merupakan hak dasar yang secara kodrati melekat pada diri manusia, bersifat universal dan langgeng. Oleh karena itu harus dilindungi, dihormati, dipertahankan, dan tidak boleh diabaikan, dikurangi atau dirampas oleh siapapun. Hal ini dapat dilihat pada UUD-NRI 1945 pada BabX tentang Hak asasi Manusia, di dalam ketentuan Pasal 28 A ditentukan: "Setiap orang berhak untuk hidup serta mempertahankan hidup dan kehidupannya". ${ }^{15}$

Kemudian Mahkamah Konstitusi meniadakan hukum tersebut dan menciptakan hukum yang baru (constitutief), "anak yang dilahirkan di luar perkawinan mempunyai hubungan perdata dengan ibunya dan keluarga ibunya serta dengan laki-laki sebagai ayahnya yang dapat dibuktikan berdasarkan ilmu pengetahuan dan teknologi dan/atau alat bukti lain menurut hukum mempunyai hubungan darah, termasuk dengan keluarga ayahnya."

Putusan ini bersifat declaratoir constitutief yang artinya menegaskan bahwa pasal 43 ayat (1) UU No. 1/1974 bertentangan dengan UUD 1945 dan kemudian meniadakan serta menciptakan hukum baru (negative legislator) tentang permasalahan kedudukan anak di luar perkawinan. Semua putusan pengadilan hanya sah dan mempunyai kekuatan hukum apabila diucapkan dalam sidang terbuka untuk umum, sehingga mempunyai 3 sifat kekuatan, yaitu 1) kekuatan untuk mengikat, 2) kekuatan sebagai pembuktian, dan 3) kekuatan eksekutorial.

Kemudian bila dikutip bunyi dari Amar Putusan Mahkamah Konstitusi No. 46/PUUVIII/2010, yaitu "anak yang dilahirkan di luar perkawinan mempunyai hubungan perdata dengan ibunya dan keluarga ibunya serta dengan laki-laki sebagai ayahnya yang dapat dibuktikan berdasarkan ilmu pengetahuan dan teknologi dan/atau alat bukti lain menurut hukum mempunyai hubungan darah, termasuk dengan keluarga ayahnya." Maka, sudah sangat jelas bahwa dalam kalimat "mempunyai hubungan darah, termasuk dengan keluarga ayahnya" koheren dengan diskursus sosiologis, yaitu : "Kekeluargaan adalah mempunyai hubungan darah". ${ }^{16}$

\section{Etnologi Masyarakat Indonesia}

Indonesia dikenal oleh dunia sebagai satu negara kepulauan yang memiliki pluralitas, kemajemukan, dan heterogenitas suku bangsa yang mendiami kepulauannya. Didalam penelitian etnologi diketahui bahwa Indonesia memiliki kurang lebih 600 suku bangsa dengan perbedaan identitasnya masing-masing dan dengan kebudayaan yang berbeda. Keberagaman yang dimiliki bangsa Indonesia dengan multi etnisnya, agamanya, rasnya, antar

14 Asmaeny Azis, Constitutional Complaint dan Constitutional Question Dalam Negara Hukum (Jakarta: Kencana, 2018), h: 75.

${ }^{15}$ Tb Ahmad Marachul Bachrain, “Analisis Putusan Mahkamah Konstitusi No. 46/Puu-Viii/2010 Tentang Anak Diluar Nikah,” Bil Dalil 1, no. 01 (January 11, 2017): 121-50.

${ }^{16}$ Nur Najwa Hanani Abd Rahman et al., "Transformasi Hubungan Kekeluargaan Saudara Kita Dari Sudut Emosi Selepas Memeluk Islam Di Johor," Jurnal ILMI 1, no. 1 (August 1, 2016), http://journal.kuim.edu.my/index.php/JILMI/article/view/42. 
DISKURSUS SOSIOLOGI PUTUSAN...

golongannya adalah suatu keberagaman yang sejati berada dalam satu bangsa dan Negara Indonesia berdasarkan pancasila sebagai falsafah bangsa. ${ }^{17}$

Dalam sistem kekerabatan masyarakat adat Indonesia, keturunan merupakan hal yang sangat penting guna meneruskan garis keturunan (clan). Oleh orang tua, anak dianggap sebagai penerus generasinya, juga dipandang sebagai wadah penerus semua harapan orangtuanya kelak di kemudian hari, anak juga dipandang sebagai pelindung orangtuanya kelak bila orangtua sudah tidak mampu lagi secara fisik untuk mencari nafkah sendiri. ${ }^{18}$ Semisal masyarakat Bali dimana anak lakilaki nantinya akan meneruskan Pura keluarga untuk berdoa kepada para leluhurnya (Patrilineal). Anak kandung memiliki kedudukan yang penting dalam tiap somah (gezin) dalam masyarakat adat.

Kemudian bila kita bergeser ke daerah barat Indonesia terdapat masyarakat Minangkabau yang diketahui bersama adalah salah satu masyarakat matrilinieal terbesar di dunia. Perempuan adalah pewaris harta pusaka keluarga. Dalam keluarga tradisional Minangkabau, garis keturunan dirujuk pada ibu, dan ayah dianggap tamu dalam keluarga. Kekuasaan sangat dipengaruhi penguasaan aset ekonomi tapi pria dari pihak perempuan memiliki legitimasi kekuasaan pada komunitasnya.

Pada umumnya keturunan mempunyai hubungan hukum yang berdasarkan pada hubungan darah, antara lain adalah hubungan antara orang tua dengan anak- anaknya. Kemudian akibat hukum yang berhubungan dengan kondisi mempunyai ketunggalan leluhur yang sama, namun akibat hukum tersebut diatas tidaklah sama diseluruh daerah.

Meskipun akibat hukum yang berhubungan dengan ketunggalan leluhur tidak sama disetiap daerah Indonesia, tapi dalam kenyataanya terdapat suatu pandangan pokok yang sama bahwa keturunan adalah unsur yang hakiki, dalam hal ini adalah sebuah hubungan darah. ${ }^{19}$

Hubungan anak yang lahir diluar perkawinan disetiap daerah mempunyai pandangan yang berbeda-beda. Pada daerah mentawai, timor, minahasa, dan ambon, wanita yang melahirkan anak itu sudah dianggap sebagai ibu dari anak yang bersangkutan secara sah. Jadi, seorang wanita yang melahirkan anak diluar perkawinan menjadi suatu kejadian normal seperti wanita yang melahirkan anak dalam perkawinan yang sah. Hal tersebut juga berbeda pada daerah lainnya. Ada yang berpendapat wajib mencela wanita yang melahirkan anak diluar perkawinan beserta anak yang dilahirkannya. Bahkan lazimnya wanita dan anak tersebut dibuang dari warga pesekutuannya, terkadang ada yang dibunuh, dirajam, atau dipersembahkan kepada raja sebagai budak. ${ }^{20}$ Adapun hal-hal yang menyebabkan tidakan tersebut adalah dikarenakan takut adanya kelahiran yang tidak dihahului oleh upacara-upacara adat yang diperlukan sesuai dengan daerah masing-masing.

\section{Sistem Kekerabatan Secara Antropologi}

Sistem kekerabatan merupakan salah satu pranata sosial yang tidak dapat dipisahkan dari kehidupan ummat manusia. Asumsi ini dibangun dari konsep pemikiran Wilken yang mendeskripsikan bahwa pada hakikatnya kehidupan manusia berasal dari suatu komunitas kecil (keluarga) yang di dalamnya terdapat lebih dari satu individu sebagai anggota kelompok. Pembentukan kelompok masyarakat manusia dimaksud bermula dari keluarga kecil yang terdiri dari

17 Abd Mu'id Aris Shofa, "Memaknai Kembali Multikulturalisme Indonesia Dalam Bingkai Pancasila," JPK (Jurnal Pancasila Dan Kewarganegaraan) 1, no. 1 (July 27, 2016): h: 38.

${ }^{18}$ Fahrul Rizal, Muhammad Aqhso, and Maraganti Harahap, "Nilai Anak Bagi Orang Tua Di Jalan Sekata Lorong Enam," SABILARRASYAD: Jurnal Pendidikan dan Ilmu Kependidikan 3, no. 2 (2018): 69-77.

${ }^{19}$ P. N. H. Simanjuntak, Hukum Perdata Indonesia (Kencana, 2017), h: 165.

${ }^{20}$ Bernadeta Resti Nurhayati, "Status Anak Luar Kawin Dalam Hukum Adat Indonesia," Jurnal Komunikasi Hukum (JKH) 3, no. 2 (August 16, 2017): 92-100, https://doi.org/10.23887/jkh.v3i2.11827. 


\section{DISKURSUS SOSIOLOGI PUTUSAN...}

ayah, ibu dan anak yang membentuk sistem kekerabatan tertentu. Sistem kekerabatan yang diperkenalkan teori Wilken pada mulanya disebut sebagai sistem kekerabatan patri liner yang menempatkan salah satu anggota kekerabatan sebagai pemimpin (kepala keluarga). ${ }^{21}$

Sistem kekerabatan merupakan unit social yang terjalin karena adanya hubungan darah atau terjadinya hubungan perkawinan. Sistem kekerabatan di Indonesia sesuai dengan Hukum adat yang berlaku mengandung makna sesuai dengan daerah masing-masing, antara lain:

Patrilineal adalah sistem kekerabatan yang ditarik dari garis keturunan ayah atau sering dikenal dengan patriarchaat. Dalam sistem kekerabatan patrilineal ini kedudukan laki-laki lebih diutamakan dibandingkan dengan perempuan. ${ }^{22}$ Secara sederhana tentunya akibat hukum dari sistem ini adalah selain hak-hak ,segala sesuatu yang terjadi terhadap sebuah keluarga adalah tanggung jawab pihak keluarga dari garis ayah. Contoh penganut sistem patrilineal di Indonesia adalah suku Batak, gayo, Rejang, Lampung, dan Bali.

Matrilineal atau sering disebut dengan matriarchaat merupakan sistem kekerabatan yang ditarik dari garis keturunan ibu. Sistem kekebaratan matrilineal di Indonesia dianut oleh suku Minangkabau. ${ }^{23}$ Apabila dalam sistem patrilineal tanggung jawab sepenuhnya menjadi tanggung jawab pihak keluarga garis ayah, edangkan sistem matrilineal sepenuhnya menjadi tanggung jawab keluarga garis ibu. Misalnya terdapat sebuah tragedi kecelakaan yang menimpa keluarga yang terdiri dari Ayah, Ibu dan Anak. Peristiwa tersebut mengakibatkan kematian Ayah dan Ibu, sedangkan dan sang Anak selamat, maka kepengurusan dan pemeliharaan anak menjadi tanggung jawab keluarga dari garis Ibu.

Parental adalah sistem kekerabatan yang menghubungkan garis keturanan dari kedua orang taunya. Anak juga menghubungkan diri dengan kerabat Ayah- Ibunya secara Bilateral. Dalam sistem ini orang tua maupun kerabat dari Ayah- Ibunya mempunyai peraturan yang sama baik tentang perkawinan, kewajiban memberi nafkah, penghormatan, pewarisan maupun pemeliharaan. Sistem kekerabatan ini dianut oleh masyarakat Jawa, Aceh, Kalimantan, dan sebagainya. Perkawinan merupakan salah satu cara utama yang digunakan untuk mempertahankan keberlanjutan tiga sistem kekerabatan diatas. Pada prinsipnya manusia akan berkembang dengan adanya perkawinan yang menimbulkkan keturunan, mempertahankan silsilah, dan kedudukan sosial. Oleh sebab itu sistem kekerabatan dalam hukum adat mengandung diskriminasi kedudukan social dan hukum antara laki-laki dan perempuan. Hal ini dapat dipahami karena hukum adat lahir dari pengalaman dan sejarah masing-masing kelompok masyarakat.

\section{Impact Putusan Mahkamah Konstitusi No. 46/PUU-VIII/2010 terhadap Sistem Kekerabatan}

MK mempertimbangkan kondisi seorang anak yang dilahirkan tanpa status yang jelas siapa ayahnya, seringkali mendapatkan perlakuan dan stigma yang tidak baik di tengah-tengah kehidupan masyarakat. Oleh karena itu, hukum harus hadir memberikan perlindungan dan kepastian hukum atas anak yang dilahirkan beserta hak hak yang melekat kepadanya. Begitupun terhadap anak yang status perkawinan orang tuanya masih dipersengketakan. ${ }^{24}$

\footnotetext{
${ }^{21}$ Eliza Meiyani, "Sistem Kekerabatan Orang Bugis Di Sulawesi Selatan (Suatu Analisis Antropologi - Sosial)," Al-Qalam 16, no. 2 (August 12, 2018): 181-90, https://doi.org/10.31969/alq.v16i2.484.

${ }^{22}$ Ellyne Dwi Poespasari, Perkembangan Hukum Waris Adat Di Indonesia (Jakarta: Zifatama Publisher, 2014), h: 9 .

${ }^{23}$ Titik Triwulan Tutik, Hukum Perdata Dalam Sistem Hukum Nasional (Jakarta: Kencana, 2015), h: 307.

24 Sarifudin Sarifudin and Kudrat Abdillah, "Putusan Mahkamah Konstitusi No. 46/Puu-Viii/2010 Dalam Bingkai Hukum Progresif," Jurnal Yuridis 6, no. 1 (June 28, 2019): 94-111, https://doi.org/10.35586/jyur.v6i1.788.
} 
DISKURSUS SOSIOLOGI PUTUSAN...

Perkawinan didasarkan pada hubungan serta ikatan batin antara pria dan wanita sebagai calon mempelainya. Ikatan batin itu diharapkan akan menjadi pondasi bagi keutuhan perkawinan agar bisa berlangsung selamalamanya, karena UU Perkawinan menganut Asas Monogami yang hanya memperbolehkan seorang laki-laki menikah dengan seorang perempuan sekali dalam hidupnya, yang semata-mata dilakukan untuk mencapai ridho Tuhan dan membentuk keluarga yang bahagia. Dalam Pasal 2 UU Perkawinan disebutkan bahwa, "Perkawinan adalah sah apabila dilakukan menurut hukum masing-masing agamanya dan kepercayaannya itu". ${ }^{25}$

Penyimpangan-penyimpangan masyarakat saat ini menjadi gejolak sosial salah satunya adalah hubungan antara pria dan wanita sehingga menimbulkan suatu kejadian ubnormal. Fenomena yang terjadi pasca Putusan MK No. 46/PUU-VIII/2010 adalah penolakan-penolakan yang muncul dimasyarakat yang menganggap bahwa putusan tersebut adalah angin segar bagi pelaku pelacuran, pemerkosaan, kumpul kebo yang memiliki anak akibat perbuatannya. Sedangkan hal tersebut diatas adalah reaksi resisten wajar yang muncul berdasarkan framing golongan dengan satu anggle sudut pandang.

Faktanya Mahkamah Konstitusi menetapkan sesuatu berdasarkan case yang diajukan kepada masyarakat berdasarkan sebuah peristiwa, melainkan bukan atas inisiatif dan daya kreatifitas semata. Namun ada unsur fenomena sosiologi sebelumnya.

Menjadi hal menarik apabila komparasikan dengan pendapat Pakar hukum adat dan hukum Islam Prof. Dr. Hazairin yang menjelaskan mengenai sistem kekeluargaan yang dikehendaki oleh Islam adalah parental atau bilateral. Argumen Hazairin dalam hal ini dapat dilihat secara konkret pada perkawinan antara Ali bin Abi Talib (603 M-40 H/661 M) dan Fatimah az-Zahra (605- 633 M), yang sama-sama berasal dari satu klan (sepupu). ${ }^{26}$ Demikian terjadi karena sistem Patrilineal dan Matrilineal melarang perkawinan sepupu sejajar Ibu maupun Ayah.

Selanjutnya dapat dilihat kembali berdasar penjelasan sebelumnya bahwa konsep parental atau bilateral adalah orang tua maupun kerabat dari Ayah-Ibu berlaku peraturan yang sama baik tentang perkawinan, kewajiban memberi nafkah, penghormatan, pewarisan maupun pemeliharaan. Hal tersebut memungkinkan banyak fleksibilitas dalam warisan dan tempat tinggal. Sistem kekerabatan menjadi lebih erat karena saling mengenali kerabat di kedua sisi ayah-ibu, dapat mewarisi dari kedua sisi, dan memungkinkan untuk tinggal bersama kerabat di kedua sisi atau sendiri. Kewajiban kekerabatan sistem parental atau bilateral dapat lancar dan bisa dinegosiasikan satu sama lain.

Peraturan sistem kekerabatan bilateral saat ini menjadi semakin umum di dunia modern, di mana aturan warisan dan tempat tinggal yang kaku dihancurkan oleh urgensi hidup dan bekerja di ekonomi industri. Sistem kekerabatan bilateral juga banyak dijumpai pada masyarakat "tradisional", bahkan dari periode pra-modern. Umumnya berada di Asia Tenggara, seperti yang didokumentasikan dalam etnografi orang Melayu, Filipina, di seluruh Indonesia (Jawa, Bali, Kalimantan), dan Thailand. Karena keturunan dan pewarisan yang tidak dipraktikkan dan diimplementasikan, orang biasanya tidak ingat hubungan kekerabatan di luar mereka, generasi kakek- nenek. Ini disebut "amnesia genealogis". ${ }^{27}$

${ }^{25}$ Siti Maghfiroh, "Implikasi Putusan Mahkamah Konstitusi Nomor 46 / PUU-VIII/ 2010 Terhadap Tunjangan Anak Luar Kawin Pegawai Negeri Sipil," Novum: Jurnal Hukum 5, no. 3 (July 15, 2018): 129-38, https://doi.org/10.26740/novum.v5n3.p129-138.

${ }^{26}$ Idris Mahmudi, "Metodologi Pembaharuan Hukum Islam Dalam Perspektif Pemikiran Hazairin," Al-Fikra : Jurnal Ilmiah Keislaman 5, no. 2 (July 28, 2017): 175-94.

27 Ahmad Badawi, Warisan Menurut Hukum Islam Dan Adat Jawa: Studi Kasus Di Kecamatan Medan Sunggal (Sleman: Deepublish, 2019), h: 53. 


\section{DISKURSUS SOSIOLOGI PUTUSAN...}

Demikan terjadi koherensi antara Sistem Kekerabatan parental atau bilateral dengan Putusan Mahkamah Konstitusi No. 46/PUU-VIII/2010 pada amarnya berbunyi "anak yang dilahirkan di luar perkawinan mempunyai hubungan perdata dengan ibunya dan keluarga ibunya serta dengan laki-laki sebagai ayahnya yang dapat dibuktikan berdasarkan ilmu pengetahuan dan teknologi dan/atau alat bukti lain menurut hukum mempunyai hubungan darah, termasuk dengan keluarga ayahnya."

Secara umum model penafsiran yang digunakan oleh Mahkamah Konstitusi ialah metode argumentum a contrario, bahwa apabila undang-undang menetapkan hal-hal tertentu untuk peristiwa tertentu, maka peraturan itu terbatas pada peristiwa itu dan untuk peristiwa di luarnya berlaku kebalikannya. Metoda seperti ini diperbolehkan dalam rangka penemuan hukum. Penafsiran berlawanan yaitu menafsirkan atau menjelaskan undang-undang yang didasarkan pada perlawanan pengertian antara peristiwa konkrit yang dihadapi dengan peristiwa yang diatur dalam undangundang.

Dalam hal Putusan Mahkamah Konstitusi Nomor 46/PUU-VIII/2010 pun demikian telah dilakukan oleh Hakim yang berwenang. Kondisi yang menuntut intelektualitas menyebabkan Hakim berfikir dengan skala yang luas dan mempertimbangankan disiplin ilmu lain dalam penemuan hukumnya, semisal efek sosiologis yang dalam hal ini tentunya sesuai dengan tugas hakim yaitu,"Hakim dalam menyelesaikan perkara-perkara yang diajukan kepadanya, wajib memperhatikan dengan sungguh-sungguh nilai-nilai hukum yang hidup dalam masyarakat, sehingga putusannya sesuai dengan rasa keadilan". ${ }^{28}$

\section{Kesimpulan dan Saran}

Putusan Mahkamah Konstitusi Nomor 46/PUU-VIII/2010 tidak bertentangan dan bersingungan dengan diskursus sosiologis. Hal tersebut sesuai dengan metode argumentum a contrario yang digunakan oleh Mahkamah Konstitusi dalam penemuan hukum. Konsep parental atau bilateral adalah orang tua maupun kerabat dari Ayah-Ibu mempunyai peraturan yang sama baik tentang perkawinan, kewajiban memberi nafkah, penghormatan, pewarisan maupun pemeliharaan. Sehingga terjadi koherensi antara Sistem Kekerabatan parental atau bilateral dengan Putusan Mahkamah Konstitusi No. 46/PUU-VIII/2010 dalam penerapannya di Indonesia. Kondisi tersebut menuntut intelektualitas Hakim yang diharuskan untuk berfikir dengan skala yang luas dan mempertimbangankan disiplin ilmu lain dalam penemuan hukumnya.

\section{E. Daftar Pustaka}

Adi, Hardian Mukti. "Pengaruh Putusan Mahkamah Konstitusi Nomor 46/Puu-Viii 2010 Terhadap Hak Waris Anak Yang Lahir Di Luar Kawin Menurut Kitab Undang-Undang Hukum Perdata." Jurnal Hukum Prodi Ilmu Hukum Fakultas Hukum Untan (Jurnal Mahasiswa S1

Fakultas Hukum) Universitas Tanjungpura 4, no. 1 (December 16, 2015). https://jurnal.untan.ac.id/index.php/jmfh/article/view/12842.

Azis, Asmaeny. Constitutional Complaint dan Constitutional Question Dalam Negara Hukum. Jakarta: Kencana, 2018.

Bachrain, Tb Ahmad Marachul. “Analisis Putusan Mahkamah Konstitusi No. 46/Puu-Viii/2010 Tentang Anak Diluar Nikah.” Bil Dalil 1, no. 01 (January 11, 2017): 121-50.

${ }^{28}$ Pusat Pengkajian Hukum Ekonomi Syariah (PPHIM), Kompilasi Hukum Ekonomi Syariah (Jakarta: Prenada Media, 2019), Pasal: 229. 
DISKURSUS SOSIOLOGI PUTUSAN...

Badawi, Ahmad. Warisan Menurut Hukum Islam Dan Adat Jawa: Studi Kasus Di Kecamatan Medan Sunggal. Sleman: Deepublish, 2019.

Dwi Poespasari, Ellyne. Perkembangan Hukum Waris Adat Di Indonesia. Jakarta: Zifatama Publisher, 2014.

Hakim, Fikri, Nani Darmayanti, and Ani Rachmat. "Pemberitaan Konflik Antara Viking Dan Jakmania Dalam Viva.Co.Id: Suatu Kajian Wacana Kritis.” Jurnal Linguistik Terapan 8, no. 1 (May 31, 2018): 33-41.

Harman, Benny K. Mempertimbangkan Mahkamah Konstitusi. Jakarta: Kepustakaan Populer Gramedia, 2013.

Iskandar, Dadang. "Politik Hukum Mahkamah Konstitusi Tentang Status Anak Luar Kawin Dalam Putusannya Nomor 46/PUU-VIII/2010.” YUSTISI 2, no. 1 (April 5, 2016): 27. https://doi.org/10.32832/yustisi.v2i1.197.

Latifiani, Dian. "Permasalahan Pelaksanaan Putusan Hakim." ADHAPER: Jurnal Hukum Acara Perdata 1, no. 1 (2015): 15-29-29.

Maghfiroh, Siti. "Implikasi Putusan Mahkamah Konstitusi Nomor 46 / PUU-VIII/ 2010 Terhadap Tunjangan Anak Luar Kawin Pegawai Negeri Sipil.” Novum : Jurnal Hukum 5, no. 3 (July 15, 2018): 129-38. https://doi.org/10.26740/novum.v5n3.p129-138.

Mahmudi, Idris. "Metodologi Pembaharuan Hukum Islam Dalam Perspektif Pemikiran Hazairin." Al-Fikra : Jurnal Ilmiah Keislaman 5, no. 2 (July 28, 2017): 175-94.

Meiyani, Eliza. "Sistem Kekerabatan Orang Bugis Di Sulawesi Selatan (Suatu Analisis Antropologi - Sosial)." Al-Qalam 16, no. 2 (August 12, 2018): 181-90. https://doi.org/10.31969/alq.v16i2.484.

Nurhadi, Nurhadi. "Implementasi Putusan Mahkamah Konstitusi Nomor 46/PUU-VIII/2010 Tentang Anak Di Luar Kawin.” Jurnal Yudisial 11, no. 2 (August 30, 2018): 243-65. https://doi.org/10.29123/jy.v11i2.66.

Nurhayati, Bernadeta Resti. "Status Anak Luar Kawin Dalam Hukum Adat Indonesia." Jurnal Komunikasi Hukum (JKH) 3, no. 2 (August 16, 2017): 92-100. https://doi.org/10.23887/jkh.v3i2.11827.

Rachman, Taufik. "Menag: Putusan MK Melebihi Permohonan Machica Mochtar." Republika Online, April 10, 2012. https://republika.co.id/berita/nasional/hukum/12/04/10/m29geymenag-putusan-mk-melebihi-permohonan-machica-mochtar.

Rahman, Nur Najwa Hanani Abd, Razaleigh Muhamat @ Kawangit, Siti Aishah Yahya, and Mohd Sufiean Hassan. "Transformasi Hubungan Kekeluargaan Saudara Kita Dari Sudut Emosi Selepas Memeluk Islam Di Johor." Jurnal ILMI 1, no. 1 (August 1, 2016). http://journal.kuim.edu.my/index.php/JILMI/article/view/42.

Respationo, HM Soerya, and M. Guntur Hamzah. "Putusan Hakim: Menuju Rasionalitas Hukum Refleksif Dalam Penegakan Hukum.” Yustisia Jurnal Hukum 2, no. 2 (May 1, 2013). https://doi.org/10.20961/yustisia.v2i2.10194.

Rizal, Fahrul, Muhammad Aqhso, and Maraganti Harahap. "Nilai Anak Bagi Orang Tua Di Jalan Sekata Lorong Enam.” Sabilarrasyad: Jurnal Pendidikan dan Ilmu Kependidikan 3, no. 2 (2018): 69-77.

Rizqy, Mochammad Fahruz. "Implikasi Yuridis Putusan Mk Nomor 46/Puu-Viii/2010 Terkait Perlindungan Hak Anak." Yuridika 30, no. 2 (May 9, 2015): 278-306. https://doi.org/10.20473/ydk.v30i2.4652. 
DISKURSUS SOSIOLOGI PUTUSAN...

Rosadi, Edi. "Putusan Hakim Yang Berkeadilan.” Badamai Law Journal 1, no. 2 (September 27, 2016): 381. https://doi.org/10.32801/damai.v1i2.1850.

Sarifudin, Sarifudin, and Kudrat Abdillah. "Putusan Mahkamah Konstitusi No. 46/PUU-VIII/2010 Dalam Bingkai Hukum Progresif.” Jurnal Yuridis 6, no. 1 (June 28, 2019): 94-111. https://doi.org/10.35586/jyur.v6i1.788.

Shofa, Abd Mu'id Aris. "Memaknai Kembali Multikulturalisme Indonesia Dalam Bingkai Pancasila." JPK (Jurnal Pancasila Dan Kewarganegaraan) 1, no. 1 (July 27, 2016): 34-40.

Simanjuntak, P. N. H. Hukum Perdata Indonesia. Kencana, 2017.

Suadi, Amran. Penyelesaian Sengketa Ekonomi Syariah Teori dan Praktik Ed Revisi. Jakarta: Kencana, 2017.

Suadi, Amran, and Mardi Candra. Politik Hukum: perspektif hukum perdata dan pidana Islam serta ekonomi syariah. Jakarta: Prenada Media, 2016.

Syariah (PPHIM), Pusat Pengkajian Hukum Ekonomi. Kompilasi Hukum Ekonomi Syariah. Jakarta: Prenada Media, 2019.

Tanuraharja, Gratia Nathania. "Implikasi Putusan Mahkamah Konstitusi Nomor 46/PUU-VIII/2010 Terhadap Bagian Waris Anak Luar Kawin.” E-Journal Universitas Atma Jaya Yogyakarta, December 13, 2015, 1-11.

Tutik, Titik Triwulan. Hukum Perdata Dalam Sistem Hukum Nasional. Jakarta: Kencana, 2015. 